\title{
8. Late careers in Hungary: Coping with the transformation from a socialist to a market economy
}

\section{Alberto Veira-Ramos and Erzsébet Bukodi}

\section{INTRODUCTION}

The transformation of the Hungarian economy after the fall of the communist regime had a tremendous effect on the careers of Hungarian workers. The reforms and changes since 1988 have impacted on both young and senior workers, and have greatly determined their life chances (Bukodi and Róbert $2002,2003)$. Kolosi and Róbert (2004) revealed that one-third of the population left the labor market between 1988 and 2003. Whereas one-half of these left paid employment because they had reached normal retirement age, the other half was more or less compelled to leave the labor market. Apart from the transition to capitalism, the process of growing international competition known as globalization might also have had relevant effects on the late careers of Hungarian workers. A substantial body of literature (e.g., Beck 1992; Giddens 1999) anticipates increasing risks in individual life courses and regards globalization as the main driving force behind this development. However, other scholars emphasize the national path dependency of this process: specific institutional arrangements such as educational systems, the regulation of the labor market, or welfare state provisions may reshape the impact of globalization on individuals' life chances (Blossfeld 2001; Blossfeld, Buchholz and Hofäcker 2006; Buchholz et al. 2009).

In this chapter, we first outline how macro-economic developments and the institutional context have influenced the Hungarian labor market during the period of economic and social transformation. We describe the main labor market trends, the changes of retirement policies, and the role of the educational system. In the following section, we present our hypotheses on how these macro-economic and institutional changes have influenced the late careers of Hungarian workers, and its consequences on pension income. 
Then, we describe the statistical methods used in our analyses. In the empirical part, we provide estimates from event history models predicting the risk of unemployment and the likelihood of early exit from the labor force via normal retirement or disability pension. We also provide estimates from a linear regression model examining the determinants of pension income. In our analyses, we use data from the Household Monitor Survey conducted by the TÁRKI Social Research Center in 2003. This is the most appropriate data source available, and provides the necessary information for the period between 1988 and 2003 .

\section{ECONOMIC DEVELOPMENT AND INSTITUTIONAL CONTEXT}

\section{Main Labor Market Trends}

The collapse of communism entailed a series of major changes in the Hungarian labor market. Many jobs were destroyed immediately after the change of regime; but later on, during the $1990 \mathrm{~s}$, job creation rates increased and job destruction rates fell (Commander and Köllö 2004). The creation of jobs was more intense in new private firms, whereas job destruction was the dominant trend in state-owned and privatized firms with rather old equipment. Kézdi (2002) has argued that job creation and job destruction varied substantially during the different phases of the transition to a market economy. Major destruction of low-skilled jobs and large intersectorial reallocation, partly toward skill-intensive industries, was strongest until 1995, during the transitional crises. After 1996, employment started to rise, and a pervasive skill upgrade has been seen in all sectors ever since. Overall, job creation in new firms has tended to be biased against employees with low educational attainments. It must be said that the demand for unskilled labor already started to diminish at the end of the socialist period, but it dropped even more sharply after the regime change. The number of jobs available to people with elementary school education or vocational training fell by 48 percent between 1990 and 1995, and has not risen subsequently. Skill expectations in manual work shifted upward, so that the traditional whiteand blue-collar divide gradually disappeared (Commander and Köllö 2004). With such an evolution of employment demand, Kertesi and Köllö (2002) concluded that the two principal changes in the labor market during the transition period were a considerable increase in the returns to skill, and a marked decrease in the returns to age and employment experience. As a result, the initial wage disadvantage of young people relative to older cohorts diminished. In other words, the transition resulted in strong discrimination against (older) unskilled workers who disproportionately lost employment in comparison to their more skilled (and younger) counterparts.

\section{Early Retirement and Disability Pensions}

Hence, it is not surprising that the employment rate of senior workers decreased sharply during the transitional crisis, and this was fostered by various incentives for early exit: instead of mass dismissals, Hungarian firms made use of early retirement and disability pension schemes as the least painful means of workforce reduction. There was, in fact, a rapid increase in the number of individuals covered by early retirement and disability pensions schemes until the mid-1990s (Széman 1994; Köllö and Nacsa 2004). In 1991-97, early retirement accounted for a high and growing percentage of total retirement, rising from 23 percent in 1991 to 30 percent in 1997. However, when the government decided to raise the retirement age and introduce stricter conditions for participating in disability schemes, early retirement first dropped to 17 percent by 1998 and then to 3-4 percent by 2001 .

At the beginning of the economic transition, labor market participation was high for employees of all ages, but it then decreased almost evenly across age groups. Employment rates of most age groups started to rise again only in 1997, but showed only little change among senior workers. Their employment rates increased only between 1999 and 2003 - reflecting the above-mentioned policy changes. Even though eligibility conditions for early retirement and disability pension have been tightened up gradually in recent years, only a small minority of the population over 55 years of age is currently participating in the labor market due to the use of mass early retirement schemes in previous years.

It is also noteworthy that according to census data, a significant number of Hungarians aged 55-59 receive some kind of disability payment, whereas this figure is much lower for people over 60 . We believe this indicates that choosing disability pension was another widespread means for senior employees to exit from the labor market during the economic crisis and even also during the following period of economic recovery, when access to normal retirement was restricted, as is described in the next section.

Table 8.1 Distribution of individuals aged 50-64 by employment status (2001)

\begin{tabular}{lrrrrrr}
\hline & \multicolumn{3}{c}{ Men } & \multicolumn{3}{c}{ Women } \\
\hline & $50-54$ & $55-59$ & $60-64$ & $50-54$ & $55-59$ & $60-64$ \\
\hline Working & 61.9 & 44.3 & 4.9 & 58.8 & 11.4 & 1.1 \\
Working retired & 1.4 & 2.0 & 4.8 & 1.4 & 6.0 & 3.2 \\
Unemployed & 5.5 & 3.3 & 0.4 & 3.6 & 0.8 & 0.2 \\
Retired & 3.8 & 16.6 & 77.5 & 3.6 & 61.0 & 83.8 \\
Disability pension & 20.8 & 27.5 & 11.0 & 22.1 & 14.4 & 5.0 \\
Home duties & 6.6 & 6.3 & 1.4 & 10.5 & 6.4 & 6.7 \\
Total & 100.0 & 100.0 & 100.0 & 100.0 & 100.0 & 100.0 \\
\hline
\end{tabular}

Source: Own calculations based on the Hungarian Census (2001). 


\section{Changes in Hungarian Pension Schemes}

The predecessor of the current Hungarian public pension system, established in 1929, collapsed during World War II. After the war, it was rebuilt and had greatly matured by the $1980 \mathrm{~s}$, with near-universal coverage, generous replacement rates, and very low retirement ages ( 55 for women, 60 for men; see Gál and Tarcali 2003). By 1990, the (net) wage replacement of public pension amounted to an average of 66 percent. In principle, the definedbenefit pension system provided earnings-related pensions, but massive redistribution resulted in a dysfunctional system in which incentives were mixed up with solidarity (Simonovits 1999).

The transformation crisis led to several changes in the pension system between 1989 and 1992. The formally independent Pension Insurance Fund (PI) and Health Insurance Fund (HI) were separated from the state budget, and the regulations for pension contributions and benefits were reformed. The Hungarian system continued to be a defined-benefit system based on contributions, with entry and continuing pensions being calculated contributions, with entry and continuing pensions being calculated of both contribution years and the average earnings throughout the of both contribution years and 1991 retained the degressive accrual rates of the socialist era in which 10 years of service meant 33 percent wage replacement. Every additional year up to 25 years added another 2 percent, and every additional year to 32 years yielded 1 percent, ending with a maximum of 70 percent. The law also introduced a (delayed) valorization of the assessed earnings used to determine entry pensions. The assessment of earnings is strongly degressive, but for a large portion of the newly retired in the last decade - even after contributing for at least 20 years - assessed earnings were so low that the pension needed to be replaced by the relatively decent minimum pension. The continuing pension is a simple increasing decent minimum pension. The continuing pension is a simple increasing pensions, continuing pensions have also been indexed according to national average wages since 1992 .

Overall, the public pension system succeeded in protecting the aged from poverty throughout the economic crisis of the 1990s. Though pensions lost their value relative to wages, other sources of income for the nonworking population declined much faster (Gál and Tarcali 2003). Consequently, the relative income status of pensioners improved during the last decade, thereby making pensions attractive for senior workers. As the only settled institutional making pensions attractive pensions absorbed a disproportionate part of the labor market crisis of the early transition years and provided an 'escape route' for hundreds of thousands of redundant workers. However, this development undermined the long-term stability of the system and induced an extensive reform in 1998.
Although the current Hungarian pension system consists of three pillars, these correspond only partially to those typical throughout the European Union. The first pillar is a mandatory, public, pay-as-you-go system based on defined benefits. It provides earnings-related old-age, disability and survivors' benefits assessed on the basis of average salary and number of years spent in service. It encompasses all occupational groups, though special rules (e.g., for retirement age, assessment period, or accrual rates) are applied to some occupational groups (e.g., miners, members of the armed forces). The official retirement age for women was increased by one year in every second year until 2009 , thereby raising it from age 55 to age 62 . The pensionable age for men was increased from age 61 in 1998 to 62 years in 2000 .

The fully funded, privately managed second pillar comprises mandatory private pension funds introduced in the 1998 pension reform. These are organized as nonprofit mutual savings associations in which members (the insured persons) are not only clients but also the exclusive owners of the fund. Private funds can be founded by businesses, professional associations, or representative bodies of employers or employees. Members are obliged to pay monthly contributions, whereas the employer is responsible for collecting, reporting and transferring contributions to the pension funds selected by these employees.

The first and second pillars combined constitute the mandatory pension component (a so-called 'mixed system'). The coverage of this compulsory system includes all persons who are engaged in some kind of gainful employment, and persons entering the labor market for the first time are automatically enrolled into this system. Those who acquired pension rights before 1998 could either voluntarily opt into the mixed system by September 1999 or remain in the pure pay-as-you-go scheme. The third pillar is made up of voluntary private pension funds. These were introduced in 1994 and have the same institutional and organizational settings as the second pillar funds (self-governance, co-ownership of members, individual accounts, nonprofit principle, defined contribution, capital-funded financing, etc.). Persons can enter a voluntary fund at their own discretion. Neither the second nor the third pillar can be regarded as occupational schemes in the literal sense, because the underlying contractual relationship is not between the employee and the employer but between the fund member and the pension fund. Nonetheless, employers are involved in more than one important respect. On the one hand, companies are allowed to establish second pillar private pension funds, or they may cooperate in setting up a voluntary pension fund by covering the costs related to its foundation. On the other hand, employers may supplement employees' monthly contributions to both types of funds.

There are three main types of early retirement that have not undergone any relevant changes in their regulation over the past few years. First, workers in 
physically demanding or hazardous professions are entitled to retire prior to the official retirement age. Men and women engaged in such activities for at least ten or eight years respectively are permitted to claim old-age benefit two years prior to the normal pension age. Second, those with a long duration of service (at least 33 years) are entitled to draw their pensions five (women) or two (men) years before the official retirement age. Third, anyone with at least 33 years of service may retire five years before the official age on the condition that the employer is willing to reimburse the amount of pension benefits to the State Pension Insurance Fund up to the official retirement age.

\section{Globalization, Education, and Technological Innovation}

Lelkes and Scharle (2004) have shown that the correlation between education and labor market status appears to have strengthened in the $1990 \mathrm{~s}$, because the likelihood of inactivity increased for those with low levels of education but hardly changed for the highly qualified. In 2003, only 43 percent of Hungarians aged 40-59 with just elementary education had a paid job, and 38 percent of them had already retired. Moreover, the proportion of older individuals with low education levels who are not in the labor market for at least 12 months has been gradually increasing from 'only' 3 percent in the early 1990 s to 10 percent in 2003 . These figures point to an extreme vulnerability of senior Hungarian workers with no or limited qualifications they tend to lose their jobs, and their chance of reentering the labor market is distinctively low. This vulnerability is accentuated by the relatively low pressure for workers to enter further training in Hungary. Despite a general increase in job training rates over the last decade, there has been a sharp reduction in participation in further education as a function of age: whereas 15 percent of workers aged 25-34 years participated in professional and career upgrading in 2003, the corresponding rates for those aged 35-44 years were 8 percent; and for those aged $45-54$ years, just 4 percent.

The diffusion of technological innovations fostered by the globalization process increases the rate of change in occupational structure and job content in modern societies. Structural changes result in mobility flows from declining (such as agriculture and industry) into expanding sectors (such as financial and business services or public services; see DiPrete et al. 2001) However, employees leaving the declining branches are not necessarily able to get a job in expanding industries. In Hungary, structural economic changes have strongly influenced the demand side of the labor market in recen decades. During the 1960s and 1970s, agricultural employment decreased gradually, and the country moved toward an industrial society. Employment in the service sector started to increase only in the $1980 \mathrm{~s}$ and $1990 \mathrm{~s}$, when more and more jobs were created there. However, the increasing share of service sector workers was due only partly to an increasing demand for services. It was also an outcome of the transformation-related economic crisis that led to the collapse of various spheres of state industry. Massive job dismissal took place in the heavy and chemical industries, textiles, construction, mining and agriculture (Ehrlich and Révész 1994). At the same time, by 2003, the share of service employment had increased to almost 60 percent for workers aged 40 and over: 30 percent were found in governmental services, 21 percent in distributive services (sales, transport), 7 percent in producer services (financial and business services, communication, etc.) and 2 percent in 'traditional' personal services.

\section{HYPOTHESES}

In this section, we present our research questions and hypotheses on the impact of economic transformation, pension reforms, de-industrialization, and globalization on late careers and its consequences on pension incomes.

\section{Late Careers}

\section{Changes over cohorts}

Our first hypothesis is that senior workers belonging to more recent cohorts have higher risks of suffering unemployment than their counterparts in earlie cohorts (H1). We believe that as reforms aimed to flexibilize the labor market were implemented the risks of unemployment increased, and unstable and volatile work careers became more frequent, especially in more recent cohorts. An important reason to believe that unemployment was less severe among earlier cohorts (e.g., for workers who were already over 50 at the time of the collapse of the socialist regime) is that they could profit from statesponsored early retirement policies. These policies, aimed to preven unemployment by channeling redundant senior workers out of the labor market into retirement, remained active only until the mid-1990s. Thus, for many workers who turned 50 after the regulation of early retirement was tightened up, the option of leaving the labor market early no longer existed therefore increasing their exposure to the risk of unemployment.

Our second and third hypotheses concern the transition from employment into retirement and disability pensions. We assume that the likelihood of early retirement must have decreased among more recent cohorts compared to those who were already 50 and older in 1988 (H2). After more than a decade of fertility decline, policies aiming to channel senior workers into retirement became financially unsustainable in most OECD countries, and Hungary was no exception. The pension reforms implemented by the Hungarian government during the second period of the transformation were clearly aimed at delaying the average age of retirement in the working 
population by making applications for early retirement more difficult. Another consequence of pension reforms that we expect to confirm is that, as stated earlier in this chapter, disability pensions became an alternative escape route for senior workers in the younger cohorts for whom an early retirement pension was no longer easily attainable (H3).

\section{Social inequalities}

Our next three hypotheses address social inequalities. First, we expect to confirm that social class and education are major factors conditioning the risk of unemployment in late careers (H4). On the one hand, because deindustrialization is known to diminish the returns to manual work, we expect to observe that the likelihood of suffering unemployment was higher for blue-collar workers than for white-collar employees. On the other hand, since globalization entails increasing competition, turning professional skills and higher education into crucial assets for being well positioned in the labor market, we expect to confirm that the better educated were less likely to suffer unemployment.

Second, we hypothesize that social class and education also play a crucial role in determining the relative risks of leaving the labor market either via early retirement or via disability pension (H5). We assume that the same social groups that face higher risks of unemployment also experience higher probabilities of applying for early retirement or a disability pension. Policies designed by Hungarian governments in accordance with employers' needs to actively encourage early retirement have been strongly conditioned by the dramatic economic restructuring brought about by the regime change (Bukodi and Róbert 2006). As described, such changes entailed a major shrinkage of the manufacturing and agricultural sector as well as the redundancy of less educated and less skilled workers.

Third, regarding changes over time, we expect to confirm that social inequalities have grown across the cohorts, because returns to education have increased for younger generations (Bukodi and Róbert 2002, 2003, 2006). We believe that the economic restructuring and the institutional pressures to postpone the retirement age have not impacted on all social classes and educational groups equally and, indeed, that they have brought about a trend toward increasing social inequalities (H6).

\section{Pension Income}

Regarding pension income, we propose four hypotheses. First, we assume that pension income is significantly higher among social groups that were less penalized by the de-industrialization and restructuring processes brought about by the regime change, that is to say, those with university education and belonging to the service class $(\mathrm{H} 7)$. We also propose that instabilities in late careers have a significant impact on pension income after retirement. Thus, we expect to show that workers who suffered at least one episode of unemployment during their late career prior to retirement tend to have lower pension income (H8). We also assume that workers who choose the 'disability pattern' get a lower pension income than those who left the labor market via 'normal early retirement' (H9). This would reinforce the idea that applying for disability pension became a lesser of two evils for many workers who accepted lower pension income as a means to avoid unemployment. Finally, we shall test the assumption whether the most recent cohorts have experienced a loss in pension income compared to earlier ones (H10) and also whether inequalities in pension income due to social class and educational attainment have increased over cohorts (H11).

\section{DATA AND METHODS}

We base our analyses on data from the MONITOR 2003 survey. This survey was carried out by the TÁRKI Social Research Center, and is based on a random sample of households in which all members of 15 years and older were interviewed. It is a cross-sectional survey with a retrospective employment history starting in 1988. Therefore, to analyze late careers, we organize the data as a person-year file containing both time-variant and timeconstant covariates that provide individual information for the period between 1988 and 2003. However, because information on income was collected for 2003 alone, the analyses of pension income require the design of a different data file and the use of a different statistical method of analysis.

\section{Dependent Variables and Analytical Strategy}

Transitions into unemployment, retirement and disability pensions

To examine the determinants of entering into unemployment and moving into retirement or applying for a disability pension, we consider individuals aged 40-54 who had a job in 1988 (938 cases: 412 men and 526 women). Those who became retired or disabled or simply moved out of the labor market following different paths during the observation period - from 1988 to 2003 - are dropped from the risk set, becoming right censored. Those who became reemployed, which is rather rare in the Hungarian context, are reentered into the risk set. The dependent variables are therefore binary variables taking the value 1 at the time when a given individual became unemployed, retired, or disabled but otherwise taking the value 0 . It should be noted that those who became unemployed or moved out of the labor market but did not retire or claim a disability pension are not right censored in the analyses of retirement 
and disability pensions. For the analyses on retirement, we right censor those cases that became disabled; and conversely, for the analyses on disability, we right censor those who started receiving a disability pension.

Apart from descriptive statistics and sequence analysis, the main statistical instruments are discrete-time, event history models with three destinations. Several logit models are estimated to asses the impact of an array of independent variables on the risks of suffering unemployment and moving into retirement or claiming a disability pension. Therefore, we consider three possible transitions: transition into unemployment, into retirement, and into a disability pension. We implement separate models for men and women when analyzing transitions into retirement and to a disability pension, because official ages of retirement in Hungary differed for men and women until they finally converged to age 62 in 2009 . However, for the risk of unemployment, we estimate a set of joint logit models for both men and women, including one variable controlling for gender differences.

\section{Pension income}

After restricting the sample to 913 individuals aged 50-74 years in 2003 who were already retired, we use reported pension income in 2003 to construct our metric dependent variable. First, we convert reported income in Hungarian Forint into Euros (applying the set exchange rate on September 15,2003 ) and then calculate the logarithm to reduce the effect of extreme cases.

\section{Independent variables}

All independent variables are binary except age, which is metric. As one of our main purposes is to compare three different cohorts, we include two dummies in the models to account for the effect of belonging to the later cohorts (those born between 1934 and 1938 and those born between 1939 and 1943) compared to the most recent one (those born between 1944 and 1948) that serves as our reference category.

The variables designed to capture the effect of education and social class are sets of dummies. The effect of education is accounted for by grouping individuals into four categories: those with elementary education or less, those with basic vocational training (the reference category), those with secondary education (including technical secondary, academic secondary [Gymnasium or grammar school] and postsecondary) and those with tertiary education. To assess the impact of social class, we use a collapsed version of the Erikson-Goldthorpe-Portocarero (EGP) classification. Workers are divided into five different groups: those belonging to the service class, those employed as routine non-manual employees, the self-employed, skilled manual workers (the reference category), and finally, semi-skilled and unskilled workers and agricultural laborers.
Models of retirement and disability pension also include one dummy variable accounting for the effect of having suffered an episode of unemployment after age 40 . Additionally, in order to test the possibility that the effects of some of our independent variables change across cohorts, we include interaction terms in some of our models.

For the analyses of pension income, the set of independent and control variables are age of retirement (metric), cohort, type of pension (retirement pension or disability retirement pension), gender, education, social class and one dummy variable reflecting the effect of being unemployed immediately before moving into retirement or claiming a disability pension.

\section{RESULTS}

\section{Descriptive Analyses}

Table 8.2 shows that a non-negligible number of senior workers in Hungary are indeed leaving the labor market before age 50 . It also indicates that inactivity rates at age 50 and the median retirement age for people employed at age 50 have increased over the cohorts. Table 8.2 additionally shows that not only inactivity but also self-employment at age 50 and unemployment after age 50 have grown across cohorts. Results also reflect an increase over cohorts in the proportion of people who leave the labor market by applying for a disability pension. This suggests a deterioration in the financial situation of an increasing number of pensioners, because disability pensions are, on average, lower than normal retirement pensions.

\section{Sequence Analyses}

Separate sequence analyses are performed for men and women. Our results are based on two subsamples of 117 men and 120 women. In both cases, we select individuals born between 1938 and 1942 and base both analyses on the information we have on their late careers since 1988 (when they were 46-50 years of age) until they reached age 61 .

Results for men show that 65.8 percent transited directly from employment to retirement and 6.8 percent from employment to a disability pension. Up to 11.1 percent suffered unemployment before moving into retirement, and 2.6 percent suffered unemployment before claiming a disability pension. Only 2.6 percent returned from unemployment to employment before entering retirement. Finally, we found that only 6 percent of the observed individuals kept working until the end of the observation period.

Because the official age of retirement was lower for women, it was not too much of a surprise to find that as many as 85.5 percent of them transited 
directly from work to retirement. An additional 4.2 percent moved from work to disability pension. Up to 7.5 percent entered retirement after one episode of unemployment, and only 0.8 percent remained working during the whole observation period. We believe that as the official retirement age for women rises, their late career pathways will tend to resemble those of men.

Table 8.2 Descriptive indicators for late career transitions and retirement across different birth cohorts

\begin{tabular}{|c|c|c|c|c|c|c|}
\hline \multirow{3}{*}{ Birth cohort $^{a}$} & \multicolumn{3}{|c|}{ Men } & \multicolumn{3}{|c|}{ Women } \\
\hline & 1938 & 1941 & 1945 & 1938 & 1941 & 1945 \\
\hline & -40 & -44 & -48 & -40 & -44 & -48 \\
\hline \multicolumn{7}{|l|}{ Employment status at age 50 (in \%) } \\
\hline Dependent employed & 87.22 & 70.48 & 49.65 & 75.90 & 69.19 & 67.56 \\
\hline Self-employed & 2.78 & 5.82 & 13.68 & 0.00 & 2.92 & 1.24 \\
\hline Unemployed & 0.00 & 6.67 & 3.33 & 3.61 & 3.68 & 3.84 \\
\hline Inactive & 10.00 & 17.03 & 33.34 & 20.48 & 24.21 & 27.35 \\
\hline \multicolumn{7}{|l|}{ Late career characteristics ${ }^{b}$} \\
\hline Unemployed after age 50 (in \%) & 19.44 & 17.48 & 23.16 & 7.94 & 16.79 & 18.01 \\
\hline \multicolumn{7}{|l|}{ Transition to retirement } \\
\hline $\begin{array}{l}\text { Median retirement age } \\
\text { Mean retirement age }^{\mathbf{c}}\end{array}$ & $\begin{array}{l}57.00 \\
5670\end{array}$ & $\begin{array}{l}58.00 \\
55.86\end{array}$ & 53.89 & $\begin{array}{l}54.00 \\
54.03\end{array}$ & $\begin{array}{l}53.00 \\
53.32\end{array}$ & 53.00 \\
\hline \multicolumn{7}{|l|}{ Kind of pension received (in $\%)^{b}$} \\
\hline Normal retirement pension & 94.44 & 51.46 & 7.37 & 98.41 & 89.78 & 32.30 \\
\hline Disability pension & 4.17 & 22.33 & 22.11 & 1.59 & 7.30 & 18.01 \\
\hline Not retired & 1.39 & 26.21 & 70.53 & 0.00 & 2.92 & 49.69 \\
\hline \multicolumn{7}{|l|}{ Pension income (in Euro) ${ }^{c}$} \\
\hline Median yearly pension & 2,827 & 2,850 & 2,379 & 2,340 & 2,214 & 2,356 \\
\hline Median yearly retirement pension & 2,827 & 3,204 & 3,204 & 2,301 & 2,261 & 2,471 \\
\hline Median yearly disability pension & $1,979^{\mathrm{e}}$ & 2,347 & 2,280 & $2,996^{\mathrm{e}}$ & 1,767 & 2,120 \\
\hline Average yearly pension & 3,305 & 3,273 & 2,877 & 2,668 & 2,769 & 2,846 \\
\hline Average yearly retirement pension & 3,352 & 3,674 & 3,935 & 2,662 & 2,829 & 3,299 \\
\hline Average yearly disability pension & $2,246^{\mathrm{e}}$ & 2,351 & 2,524 & $2,996^{\mathrm{e}}$ & 2,023 & 2,033 \\
\hline
\end{tabular}

Source: Own calculations based on the TARKI MONITOR survey (2003).

Notes:

Our observation window starts in 1988 and ends in 2003. Therefore, the oldest cohort is observed until it reaches $60-63$; the intermediate, until 59-62; and the most recent, until 55-

b Based on those who were still employed at the age of 50 .

Based on those who were still employed at the age of 50 and were already retired when observed in 2003

d Only 29.5 percent were retired before age 58 , the oldest age for which we have observation from this cohort in 2003.

e Estimates based on information from fewer than 10 cases.
Figure 8.1 Sequence analysis of late career pathways for Hungarian men aged 50-61 years

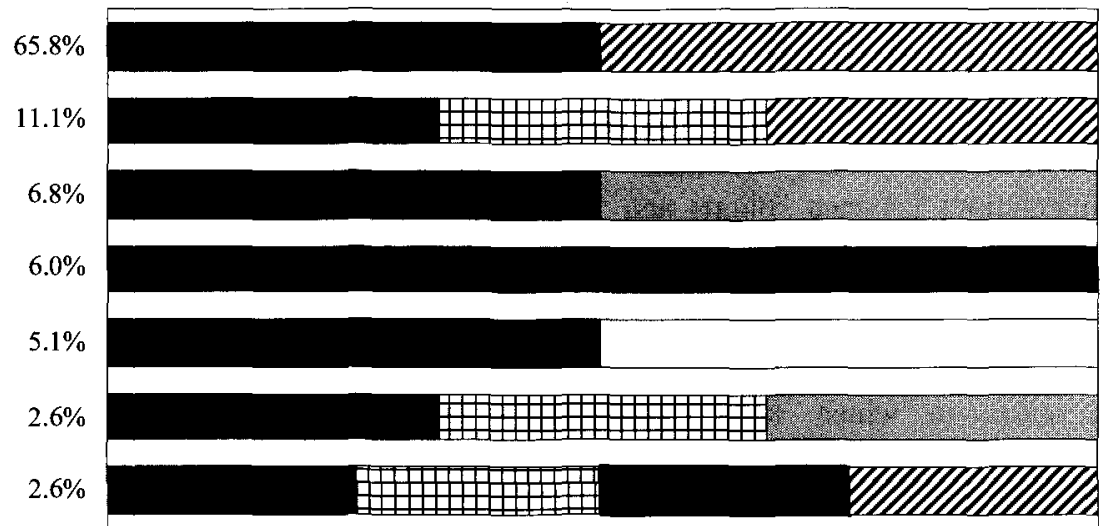

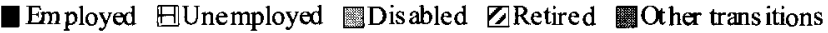
Source: Own calculations based on the TARKI MONITOR survey (1988-2003).

Figure 8.2 Sequence analysis of late career pathways for Hungarian women aged 50-61 years

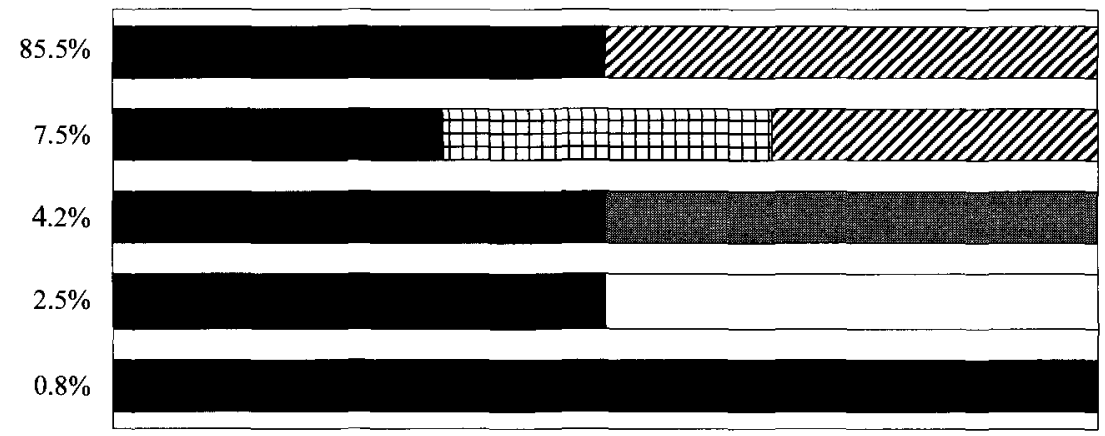

Employed Unemployed 圆Disabled

Source: Own calculations based on the TARKI MONITOR survey (1988-2003).

Logistic Regression Analyses: Transitions to Unemployment, Retirement and Disability Pension

Here we present and discuss the results from our models of transitions to unemployment, retirement and a disability pension. Each table includes one first baseline model accounting for the effects of cohort and age. Models 2 
and 3 reflect the effects of social class and education. For analyses on unemployment risks, Model 4 accounts for interaction effects between cohorts and social class and Model 5 accounts for interactions between cohorts and education. For analyses on transitions to retirement and a disability pension, Model 4 includes a dummy controlling for previous unemployment experience and Model 5 includes the interaction terms between cohorts and education. We do not show models accounting for interactions between cohorts and social class, because none of them were significant.

\section{Unemployment}

The transformation of Hungary into a market economy created a new scenario in which secure employment is no longer guaranteed by governmental doctrine. The results in Table 8.3 clearly reflect such contextual change, indicating that during their late careers the two more recent cohorts (1939-43 and 1944-48) suffered higher risks of unemployment than the oldest one (1934-38). It must be noted that the oldest cohort comprises those individuals who were already 50-54 in 1988 (when the socialist system collapsed); thus, they were 'old enough' to benefit from the generous early retirement pension provisions offered by the state during the first phase of the transition. This measure, intended to keep unemployment rates low, seems to have been quite effective.

Our models also show that unemployment risks were higher for manual workers than for white-collar employees. We also found strong evidence indicating that those who completed tertiary education were better sheltered against unemployment than the rest. Concerning the evolution of the impact of social class over time, we have not found any statistically significant trend. However, we found some signs that educational inequalities in the risk of unemployment have increased among senior workers over the period covered by this study. A significant increase in the risk of unemployment is observed for those who have only elementary or secondary education when results for the two more recent cohorts are compared. All these findings are consistent with the well-known facts that de-industrialization implies a reduction in employment opportunities for blue-collar workers and that globalization increasingly rewards the better educated.

\section{Retirement}

Estimates for the transition to early retirement shown in Tables 8.4 for men and 8.5 for women reflect how dramatically individual behavior responded to institutional changes in the Hungarian context. On the one hand, the higher likelihood of retirement experienced by workers of the oldest cohort must be interpreted as a consequence of governmental policies encouraging early
Table 8.3 Unemployment risk of Hungarian women and men in the late career (logistic regression model)

\begin{tabular}{|c|c|c|c|c|c|}
\hline & 1 & 2 & 3 & 4 & 5 \\
\hline \multicolumn{6}{|l|}{ Cohorts } \\
\hline $1934-38$ & $-1.83^{* *}$ & $-2.05 * *$ & $-2.04 * *$ & $-2.30^{*}$ & $-1.96+$ \\
\hline $1939-43$ & 0.02 & -0.05 & -0.07 & 0.12 & $0.54+$ \\
\hline $1944-48$ (ref.) & - & - & - & - & - \\
\hline Age (40 plus) & $0.04 *$ & $0.05^{* *}$ & $0.05^{* *}$ & $0.05^{* *}$ & $0.05 * *$ \\
\hline \multicolumn{6}{|l|}{ Gender } \\
\hline Male (ref.) & & - & - & - & - \\
\hline Female & & -0.07 & 0.00 & -0.07 & 0.00 \\
\hline \multicolumn{6}{|l|}{ Social class } \\
\hline Service class & & $-0.94 * *$ & & $-0.99 * *$ & \\
\hline Routine non-manual & & -0.47 & & -0.34 & \\
\hline Self-employed & & -0.90 & & -0.88 & \\
\hline Skilled worker (ref.) & & - & & - & \\
\hline Unskilled worker & & $0.53^{* *}$ & & $0.63^{*}$ & \\
\hline \multicolumn{6}{|l|}{ Education } \\
\hline Elementary & & & 0.32 & & $0.69 * *$ \\
\hline Vocational (ref.) & & & - & & - \\
\hline Secondary & & & $-0.55^{*}$ & & -0.27 \\
\hline Tertiary & & & $-1.43^{* *}$ & & $-1.61^{*}$ \\
\hline \multicolumn{6}{|l|}{ Interaction effects ${ }^{a}$} \\
\hline $1934-38 *$ Service class & & & & 1.19 & \\
\hline 1934-38* Unskilled & & & & 0.10 & \\
\hline $1939-43 *$ Service class & & & & 0.00 & \\
\hline 1939-43* Routine & & & & -0.43 & \\
\hline 1939-43* Unskilled & & & & -0.27 & \\
\hline $\begin{array}{l}1934-38 * \text { Elementary } \\
1934-38 * \text { Secondary }\end{array}$ & & & & & -0.34 \\
\hline 1934-38* Secondary & & & & & 0.38 \\
\hline $1939-43 *$ Elementary & & & & & $-1.01 * *$ \\
\hline $1939-43 *$ Secondary & & & & & $-0.88+$ \\
\hline $1939-43 *$ Tertiary & & & & & 0.26 \\
\hline Constant & $-5.64 * *$ & $* \quad-6.21 * *$ & $-6.10^{* *}$ & $-6.23 * *$ & $-6.32 * *$ \\
\hline Observations & 8,397 & 8,397 & 8,397 & 8,397 & 8,397 \\
\hline Cases & 938 & 938 & 938 & 938 & 938 \\
\hline Events & 172 & 172 & 172 & 172 & 172 \\
\hline Log Pseudo Likelihood & -827.54 & -803.09 & -805.61 & -802.31 & -801.01 \\
\hline
\end{tabular}

Source: Own calculations based on the TARKI MONITOR survey (1988-2003).

Notes:

*ffect significant at $p<0.01, *$ effect significant at $p<0.05,+$ effect significant at $p<0.10$

a Some interaction effects were not calculated due to lack of cases or events. 
retirement during the first phase of the transition. Such policies were particularly appealing to an increasing number of redundant senior workers for particularly appealing to an increasing numbeyment. On whom early retirement seemed a far better altermative than une the other hand, the decreased risk of retirement among workers in the most recent cohort is the result of several pension reforms carried out by the Hungarian government during the 1990s in order to delay the average age of

Table 8.4 Transition to retirement of Hungarian men in the late career (logistic regression model)

\begin{tabular}{|c|c|c|c|c|c|}
\hline & 1 & 2 & 3 & 4 & 5 \\
\hline \multicolumn{6}{|l|}{ Cohorts } \\
\hline $\begin{array}{l}1934-38 \\
1939-43\end{array}$ & $1.12 * *$ & $0.94^{* *}$ & $1.08^{* *}$ & $1.20^{* *}$ & $1.12^{* *}$ \\
\hline $\begin{array}{l}1939-43 \\
1944-48 \text { (ref.) }\end{array}$ & $1.03 * *$ & $0.94 * *$ & $1.01 * *$ & $1.02^{* *}$ & 0.57 \\
\hline $\begin{array}{l}\text { 1944-48 (ref.) } \\
\text { Age (40 plus) }\end{array}$ & - & - & - & - & - \\
\hline $\begin{array}{l}\text { Age ( } 40 \text { plus) } \\
\text { Social class }\end{array}$ & $0.33^{* *}$ & $0.35^{* *}$ & $0.35^{* *}$ & \multirow{2}{*}{\multicolumn{2}{|c|}{$\begin{array}{l}\text { Age (40 plus) } \\
\text { Social class }\end{array}$}} \\
\hline $\begin{array}{l}\text { Social class } \\
\text { Service class }\end{array}$ & & $-0.43^{*}$ & & & \\
\hline Routine non-manual & & 0.28 & & & \\
\hline Self-employed & & $-1.28^{*}$ & & & \\
\hline Skilled worker (ref.) & & - & & & \\
\hline Unskilled worker & & 0.30 & & & \\
\hline \multicolumn{6}{|l|}{ Education } \\
\hline $\begin{array}{l}\text { Elementary } \\
\text { Vocational (ref.) }\end{array}$ & & & 0.18 & 0.18 & -0.18 \\
\hline $\begin{array}{l}\text { Vocational (ref.) } \\
\text { Secondary }\end{array}$ & & & - & - & $-\overline{-}$ \\
\hline $\begin{array}{l}\text { Secondary } \\
\text { Tertiary }\end{array}$ & & & -0.19 & $\begin{array}{l}-0.13 \\
-0.65^{*}\end{array}$ & $\begin{array}{l}-1.16+ \\
-0.33\end{array}$ \\
\hline $\begin{array}{l}\text { Tertiary } \\
\text { Experienced unemployment }\end{array}$ & & & & $\begin{array}{r}-0.65^{*} \\
0.63^{*}\end{array}$ & $\begin{array}{c}-0.33 \\
0.61^{*}\end{array}$ \\
\hline \\
\hline $\begin{array}{l}\text { Interaction effects } \\
\quad 1934-38 * \text { Elementary }\end{array}$ & & & & & 0.02 \\
\hline $1934-38 *$ Secondary & & & & & 1.13 \\
\hline $1934-38 *$ Tertiary & & & & & -0.76 \\
\hline $1939-43 *$ Elementary & & & & & 0.82 \\
\hline $1939-43 *$ Secondary & & & & & $1.24+$ \\
\hline $1939-43 *$ Tertiary & & & & & -0.01 \\
\hline Constant & $-21.45^{* *}$ & $-22.41 * *$ & $-22.09 * *$ & $-21.87 * *$ & $-22.00^{* *}$ \\
\hline Observations & 4,157 & 4,157 & 4,157 & 4,157 & 4,157 \\
\hline Cases & 412 & 412 & 412 & 412 & 412 \\
\hline Events & 203 & 203 & 203 & 203 & 203 \\
\hline Log Pseudo Likelihood & -611.60 & -601.61 & -604.40 & -601.22 & -596.63 \\
\hline
\end{tabular}

Source: Own calculations based on the TARKI MONITOR survey (1988-2003),

Notes:

** Effect significant at $\mathrm{p}<0.01,{ }^{*}$ effect significant at $\mathrm{p}<0.05$, + effect significant at $\mathrm{p}<0.10$.

a No significant interaction effects for social class were observed. retirement. This major policy shift, common to many other European societies, was adopted as a response to the problem of demographic ageing.

Concerning social inequalities, Models 2 and 3 from both tables indicate that those who belong to the service class face lower risks of early retirement than the rest - not counting the self-employed. It is not surprising that the self-employed are the less likely to retire early, because these types of

Table 8.5 Transition to retirement of Hungarian women in the late career (logistic regression model)

\begin{tabular}{|c|c|c|c|c|c|}
\hline & 1 & 2 & 3 & 4 & 5 \\
\hline \multicolumn{6}{|l|}{ Cohorts } \\
\hline 1934-38 & $1.19 * *$ & $1.12 * *$ & $1.11 * *$ & $1.24^{* *}$ & $2.23^{* *}$ \\
\hline $1939-43$ & $0.84^{* *}$ & $0.83^{* *}$ & $0.86^{* *}$ & $0.94^{* *}$ & $1.40^{* *}$ \\
\hline $1944-48$ (ref.) & - & - & - & - & - \\
\hline Age (40 plus) & $0.34 * *$ & $0.35 * *$ & $0.36^{* *}$ & $0.35^{* *}$ & $0.36^{* *}$ \\
\hline \multicolumn{6}{|l|}{ Social class } \\
\hline Service class & & -0.31 & & & \\
\hline Routine non-manual & & -0.11 & & & \\
\hline Self-employed & & $-0.81^{*}$ & & & \\
\hline Skilled worker (ref.) & & - & & & \\
\hline Unskilled worker & & 0.16 & & & \\
\hline \multicolumn{6}{|l|}{ Education } \\
\hline Elementary & & & -0.20 & -0.21 & -0.07 \\
\hline Vocational (ref.) & & & - & - & - \\
\hline Secondary & & & $-0.42 *$ & $-0.36+$ & 0.19 \\
\hline Tertiary & & & $-1.00^{* *}$ & $-0.92 * *$ & -0.29 \\
\hline Experienced unemployment & & & & $0.55^{*}$ & $0.62 *$ \\
\hline \multicolumn{6}{|l|}{ Interaction effects ${ }^{a}$} \\
\hline $1934-38 *$ Elementary & & & & & $-0.86+$ \\
\hline $1934-38 *$ Secondary & & & & & $-1.42 * *$ \\
\hline 1934-38* Tertiary & & & & & -1.17 \\
\hline $1939-43 *$ Elementary & & & & & -0.15 \\
\hline $1939-43 *$ Secondary & & & & & $-0.85+$ \\
\hline $1939-43 *$ Tertiary & & & & & $-0.97+$ \\
\hline Constant & $-20.51^{* *}$ & * $-20.80^{* *}$ & $-21.01 * *$ & $-20.71 * *$ & $-21.51^{* *}$ \\
\hline Observations & 4,600 & 4,600 & 4,600 & 4,600 & 4,600 \\
\hline Cases & 526 & 526 & 526 & 526 & 526 \\
\hline Events & 342 & 342 & 342 & 342 & 342 \\
\hline Log Pseudo Likelihood & -929.69 & -924.75 & -919.28 & -915.75 & -909.91 \\
\hline
\end{tabular}

Source: Own calculations based on the TARKI MONITOR survey (1988-2003). Notes:

** Effect significant at $p<0.01, *$ effect significant at $p<0.05,+$ effect significant at $p<0.10$

a No significant interaction effects for social class were observed. 
workers tend to remain active until older ages in all developed economies (Blöndal and Scarpetta 1998), and Hungary does not seem to be an exception here. Plus, most early retirement plans implemented by the Hungarian government targeted mainly employees and not the self-employed (Bukodi and Róbert 2006).

Our models also indicate that men and women with tertiary education are less likely to retire early than those with lower education, even after controlling for previous unemployment experiences that are more frequent among less educated workers.

Models accounting for interaction effects between cohort and education show that social inequalities remained the same for men but increased for women when comparing the oldest (1934-38) with the intermediate (193943) cohorts. However, compared to the oldest and intermediate cohorts, the effects of education appear to be less pronounced in the most recent cohort (1944-48). We also computed models accounting for interaction effects between cohorts and social class, but no coefficient was found to be significant.

\section{Disability pension}

According to previous research, transitions into disability pension have become more common than early retirement in recent years (Bukodi and Róbert 2006). Our results shown in Tables 8.6 and 8.7 also indicate that the likelihood of applying for a disability pension has increased significantly across the three cohorts. They also confirm the existence of important social inequalities, indicating that this likelihood depends greatly on educational attainment. People with only elementary education are more prone to choose this less attractive pathway into retirement than people with vocational training or secondary education, who, in turn, are also more likely to apply for a disability pension than those with tertiary education. All this holds true even after controlling for previous unemployment experiences. With respect to social class, only the self-employed are significantly less likely than the rest to retire via a disability pension. This 'basic' inequality structure conditioning the risks of applying for a disability pension is found in each cohort, suggesting that this is the route out of the labor market for people at the lower end of the educational system, and no major changes have occurred over time.

\section{Linear Regression Analysis: Pension Income}

Results presented in Table 8.8 show that in 2003, after 15 years of economic transformation and institutional reforms, pension income in Hungary is greatly determined by social class and educational attainment.
Coefficients indicate that those who worked as white-collar employees (especially the service class) earn more after retirement than those employed as blue-collar workers. Furthermore, among manual workers, the unskilled have lower levels of pension income than the skilled. Concerning the role of education, results clearly show that the higher educated (especially those with a university degree) tend to benefit from higher pensions after retirement.

Table 8.6 Transition to disability pension of Hungarian men in the late career (logistic regression model)

\begin{tabular}{|c|c|c|c|c|c|}
\hline & 1 & 2 & 3 & 4 & 5 \\
\hline \multicolumn{6}{|l|}{ Cohorts } \\
\hline $1934-38$ & $-3.54 * *$ & $-3.74 * *$ & $-3.65^{* *}$ & $-3.46 * *$ & $-16.53^{*}$ \\
\hline $1939-43$ & $-1.13 * *$ & $-1.20 * *$ & $-1.15^{* *}$ & $-1.12 * *$ & -0.62 \\
\hline $1944-48$ (ref.) & - & - & - & - & - \\
\hline Age (40 plus) & $0.08 * *$ & $0.10 * *$ & $0.09^{* *}$ & $0.08 * *$ & $0.08 * *$ \\
\hline \multicolumn{6}{|l|}{ Social class } \\
\hline Service class & & -0.45 & & & \\
\hline Routine non-manual & & -0.45 & & & \\
\hline Self-employed & & $-1.86^{*}$ & & & \\
\hline Skilled worker (ref.) & & - & & & \\
\hline Unskilled worker & & 0.40 & & & \\
\hline \multicolumn{6}{|l|}{ Education } \\
\hline Elementary & & & $0.56^{*}$ & $0.55 * *$ & $0.61^{*}$ \\
\hline Vocational (ref.) & & & - & - & - \\
\hline Secondary & & & -0.30 & -0.29 & 0.01 \\
\hline Tertiary & & & $-0.71+$ & $-0.65+$ & -0.57 \\
\hline Experienced unemployment & & & & $0.83 * *$ & $0.80^{* * *}$ \\
\hline \multicolumn{6}{|l|}{ Interaction effects ${ }^{a}$} \\
\hline 1934-38* Elementary & & & & & 13.90 \\
\hline $1934-38 *$ Secondary & & & & & \\
\hline 1934-38* Tertiary & & & & & b \\
\hline $1939-43 *$ Elementary & & & & & -0.43 \\
\hline $1939-43 *$ Secondary & & & & & $-1.69^{*}$ \\
\hline $1939-43 *$ Tertiary & & & & & -0.32 \\
\hline Constant & $-7.51^{* *}$ & * $\quad-8.01 * *$ & * $\quad-7.80^{* *}$ & $* \quad-7.27 * *$ & * $\quad-7.40 * *$ \\
\hline Observations & 4,157 & 4,157 & 4,157 & 4,157 & 4,157 \\
\hline Cases & 412 & 412 & 412 & 412 & 412 \\
\hline Events & 94 & 94 & 94 & 94 & 94 \\
\hline Log Pseudo Likelihood & -426.72 & -416.60 & -419.30 & -415.08 & -411.74 \\
\hline
\end{tabular}

Source: Own calculations based on the TARKI MONITOR survey (1988-2003). Notes:

** Effect significant at $\mathrm{p}<0.01$, * effect significant at $\mathrm{p}<0.05$, effect significant at $\mathrm{p}<0.10$.

a No significant interaction effects for social class were observed.

b These interaction effects could not be calculated due to lack of cases or events. 
Results shown in Table 8.8 confirm that disability schemes provide less Results shown in Thich is in line with what was income than normal retirement pensions - which is in those individuals who anticipated in Table 8.2. They also indicate that those individuals who suffered unemployment prior to their exit from the labor market tend to receive lower income after retirement than those who moved directly from working to retirement or a disability pension.

Table 8.7 Transition to disability pension of Hungarian women in the late career (logistic regression model)

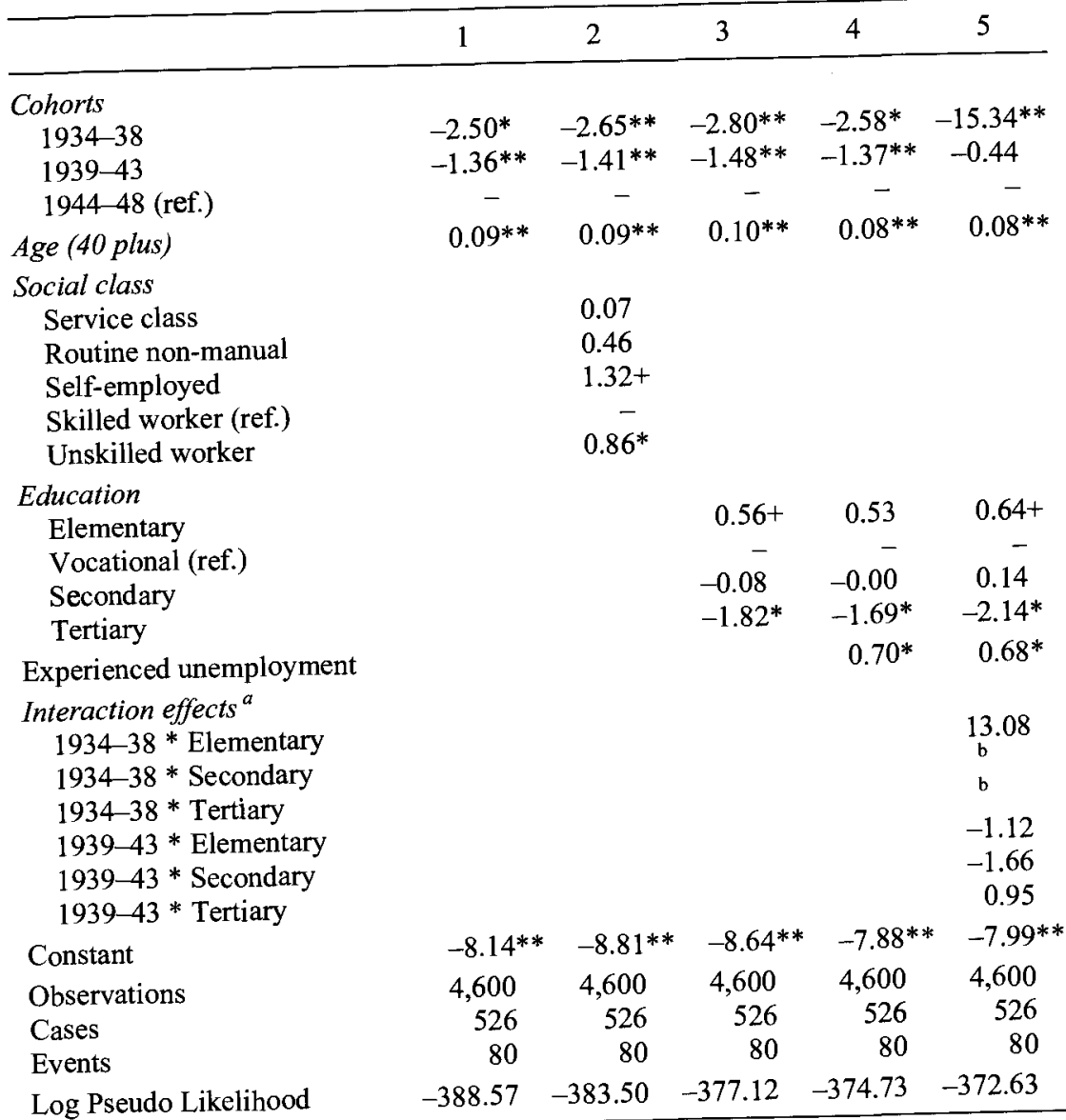

Source: Own calculations based on the TARKI MONITOR survey (1988-2003).

Notes:
$* *$ Effect significant at $\mathrm{p}<0.01$, * effect significant at $\mathrm{p}<0.05,+$ effect significant at $\mathrm{p}<0.10$.

a No significant interaction effects for social class were observed.

b These interaction effects could not be calculated due to lack of cases or events.
Our models do not provide any evidence pointing to a significant change in the levels of pension income across cohorts or suggesting a trend toward increasing inequalities between different social groups. However, it must be noted that our possibilities of exploring changes over time and across cohorts are limited, because the only information our data provides on pension income is for the year 2003 .

Table 8.8 Monthly pension income (linear regression model)

\begin{tabular}{|c|c|c|c|c|c|}
\hline & 1 & 2 & 3 & $4^{a}$ & $5^{\mathrm{a}}$ \\
\hline \multicolumn{6}{|l|}{ Cohorts } \\
\hline $1929-33$ & -0.06 & -0.05 & 0.01 & $-0.12^{*}$ & -0.10 \\
\hline $1934-38$ & -0.02 & 0.03 & $0.07+$ & $-0.07+$ & -0.08 \\
\hline $1939-43$ & -0.01 & 0.03 & 0.03 & $-0.07+$ & -0.07 \\
\hline $1944-48$ (ref.) & - & - & - & - & - \\
\hline $1949-53$ & -0.06 & -0.09 & $-0.13^{*}$ & -0.09 & -0.06 \\
\hline Age of retirement (50 plus) & $0.03 * *$ & $0.02 * *$ & $0.01 * *$ & 0.01 & 0.00 \\
\hline \multicolumn{6}{|l|}{ Gender } \\
\hline Male (ref.) & & - & - & - & - \\
\hline Female & & $-0.12 * *$ & $-0.13 * *$ & $-0.19^{* *}$ & $-0.18 * *$ \\
\hline \multicolumn{6}{|l|}{ Social class } \\
\hline Service class & & $0.38 * *$ & & & \\
\hline Routine non-manual & & $0.12^{* *}$ & & & \\
\hline Self-employed & & -0.11 & & & \\
\hline Skilled worker (ref.) & & - & & & \\
\hline Unskilled worker & & $-0.19^{* *}$ & & & \\
\hline \multicolumn{6}{|l|}{ Education } \\
\hline Elementary & & & $-0.09^{* *}$ & $-0.08^{*}$ & -0.09 \\
\hline Vocational (ref.) & & & - & - & - \\
\hline Secondary & & & $0.26 * *$ & $0.25^{* *}$ & $0.26^{* *}$ \\
\hline Tertiary & & & $0.60^{* *}$ & $0.57^{* *}$ & $0.58 * *$ \\
\hline Experienced unemployment & & & & $-0.28^{* *}$ & * $-0.12^{* *}$ \\
\hline Disability pension & & & & $-0.13 * *$ & $*-0.28 * *$ \\
\hline Constant & $3.83^{* *}$ & $4.49^{* *}$ & $4.61^{* *}$ & $5.18^{* *}$ & $5.20 * *$ \\
\hline Cases & 913 & 913 & 913 & 913 & 913 \\
\hline Log Pseudo Likelihood & -604.12 & -488.54 & -466.99 & -436.17 & -433.28 \\
\hline $\mathrm{R}^{2}$ & 0.07 & 0.28 & 0.31 & 0.36 & 0.35 \\
\hline
\end{tabular}

Source: Own calculations based on the TARKI MONITOR survey (2003). Notes:

** Effect significant at $\mathrm{p}<0.01{ }^{*}$ effect significant at $\mathrm{p}<0.05$, effect significant at $\mathrm{p}<0.10$.

a Models $\mathbf{4}$ and 5 accounted for interaction effects between cohorts and education or social class. No significant interaction effects were observed. 


\section{CONCLUSIONS}

Senior Hungarian workers were confronted with the combined effects of three major social changes within a rather short period of time. First, they experienced the transformation from a socialist to a free market economy, which put to an end the state-led policy of full employment. Second, they suffered the consequences of accelerated de-industrialization, highly conditioned by the process of increasing international competition known as globalization. And third, they had to cope with a series of pension reforms aimed at limiting the access to retirement as a consequence of the demographic aging of the Hungarian population. In this study, we have used information from three different cohorts of Hungarian workers to measure the impact of economic transformation, de-industrialization, globalization and pension reforms on their late careers and pension income.

Our comparison between workers of different cohorts confirmed our first three hypotheses: unemployment risks increased over the cohorts (H1), the likelihood of early retirement decreased (H2) and the probability of applying for disability pension increased $(\mathrm{H} 3)$. This clearly confirms that governmental policies implemented during the first phase of the transformation period succeeded in channeling large numbers of Hungarian senior workers into retirement and sparing them from unemployment. In our view, these results also prove that as early exit from the labor market into normal retirement became limited by pension reforms, late careers in Hungary have become increasingly unstable and workers are more likely to either suffer unemployment or to claim a disability pension in order to avoid it.

Besides a trend toward increasing instabilities in late careers over time, our research has also confirmed the existence of important social inequalities. We have shown that the risk of unemployment and the likelihood of retirement - in any of its forms, normal early retirement or disability pension - depend significantly on social class and educational attainment (H4 and H5). Evidence has been provided indicating that the service class and the higher educated are significantly less likely to suffer unemployment during their late careers, and also that they are less prone to apply for early retirement or to claim a disability pension. However, our models did not offer results suggesting that the observed social inequalities in late career patterns have changed significantly across the cohorts analyzed (H6)

Similar patterns of inequalities were also observed in our analysis of pension income. Pensions were found to be higher among workers of the service class and among workers with a university degree than among the remaining categories of workers $(\mathrm{H} 7)$. Results have also shown that suffering unemployment prior to retirement and claiming a disability pension rather than a normal early retirement pension are factors strongly associated with lower pension income (H8 and H9). Finally, we have found neither major differences in pension levels between the three cohorts analyzed (H10) nor a trend toward increasing social inequalities in pension income (H11).

It is clear to us that the responses implemented by Hungarian institutions and social actors to transform the economy of the country and adapt it to an environment of increasing global competition have greatly shaped the late career patterns of Hungarian workers and buffered the growth of social inequalities. More recent pension reforms - designed to cope with demographic ageing - coincide in time with a period of economic recovery that contributed to alleviating the pressure to dismiss or relocate senior workers. Nevertheless, we would expect that the social inequalities in the incomes of older people will increase in the future with the gap between the least educated and the rest becoming more pronounced. In more recent cohorts, poorly educated workers are less and less likely to accumulate the appropriate amount of 'service time' (i.e., years in employment) to be eligible for retirement schemes of any kind, and even if they are eligible, their very low wages will ensure that their pension incomes will be distinctively low. Those predicted trends are surely exacerbated by the current economic crises.

\section{NOTE}

1. The participation of Dr. Alberto Veira-Ramos in this project was possible thanks to a postdoctoral grant provided by the Spanish Ministry of Science and Innovation (MICINN) in cooperation with the Spanish Foundation for Science and Research (FECYT), (ID: 20080886). We would also like to thank Paul Schmelzer for helpful suggestions and comments.

\section{BIBLIOGRAPHY}

Beck, Ulrich (1992), Risk Society. Towards a New Modernity, London: Sage.

Blöndal, Sveinbjörn and Stefano Scarpetta (1998), 'The Retirement Decision in OECD Countries', OECD Working Paper AWP No. 1.4, Paris: OECD.

Blossfeld, Hans-Peter (2001), 'Globalization, Social Inequality and the Role of Country-specific Institutions. Open Research Questions in a Learning Society', in Pedro Conceicao, Manuel V. Heitor and Bengt-Ake Lundvall (eds), Towards a Learning Society: Innovation and Competence Building with Social Cohesion for Europe, Oxford: Oxford University Press, pp. 303-24.

Blossfeld, Hans-Peter, Sandra Buchholz and Dirk Hofäcker (2006), Globalization, Uncertainty, and Late Careers in Society, New York: Routledge.

Buchholz Sandra Annika Jabsen, Karin Kurz, Julia Marold, Paul Schmelzer and Hans-Peter Blossfeld (2009), 'Globalization, Economic Restructuring and Increasing Uncertainty in Old Age. A Theoretical Framework', flexCAREER Working Paper, Germany: University of Bamberg.

Bukodi, Erzsébet and Péter Róbert (2002), 'Men's Career Mobility in Hungary in the 1990s', GLOBALIFE Working Paper No. 38, Germany: University of Bamberg. 
Bukodi, Erzsébet and Péter Róbert (2003), 'Women's Career Mobility in Hungary in the 1990s', GLOBALIFE Working Paper No. 53, Germany: University of Bamberg.

Bukodi, Erzsébet and Péter Róbert (2006), 'Late Careers and Career Exits in Hungary', in Hans-Peter Blossfeld, Sandra Buchholz and Dirk Hofäcker (eds) Globalization, Uncertainty, and Late Careers in Society, New York: Routledge, pp. 323-52.

Commander, Simon and János Köllő (2004), 'The Changing Demand for Skills: Evidence from the Transition', IZA Working Paper No. 1073, Bonn: IZA.

DiPrete, Thomas A., Dominique Goux, Eric Maurin and Michael Tåhlin (2001), al Review, 17, 23354.

Ehrlich, Éva and Gábor Révész (1994), “Várakozások és valóság. Folyamatok 1989 és 1993 között', Közgazdasági Szemle, XLI, 192-213.

Gál, Róbert I. and Géza Tarcali (2003), 'Pension reform and intergenerational redistribution in Hungary', Paper on the PIE International Workshop on 'Pension Reform in Transition Economies', Hitotsubash: IER.

Giddens, Anthony (1999), Runaway World: How Globalisation is Reshaping our Lives?, London: Profile Books.

Kertesi, Gábor and János Köllõ (2002), 'Labour Demand with Heterogeneous Labour Inputs after the Transition in Hungary, 1992-1999', Working Papers on the Labour Market No. 5, IE-HAS, Budapest.

Kézdi, Gabor (2002), 'Two Phases of Labour Market Transition in Hungary, Intersectorial Reallocation and Skill-biased Technological Change', Working Papers on the Labour Market No. 3, Budapest: IE-HAS.

Köllö, János and Beáta Nacsa (2004), Flexibility and Security in the Labor Market Hungary's Experience, Budapest: ILO-CET.

Kolosi, Tamás and Péter Róbert (2004), 'Key processes of structural transformation and mobility in Hungarian society since the fall of communism', in Tamás Kolosi, György Vukovich and István György (eds), Social Report 2004, Budapest: TÁRKI, pp. 47-71.

Lelkes, Orsolya and Ágota Scharle (2004), 'Low Participation among Older Men and the Disincentive Effects of Social Transfers: The Case of Hungary', in Tamás Kolosi, István György Tóth and György Vukovich (eds), Social Report 2004, Budapest: TÁRKI, pp. 233-48.

Simonovits, András (1999), 'The New Hungarian Pension System and its Problems', KTK/IE Discussion Papers 1999/1, Budapest: Institute of Economics Hungarian Academy of Sciences.

Széman, Zsuzsa (1994), 'Employer Policies Towards Older Workers in Hungary', SocoProject Paper No. 11, WIIW, Vienna. 